\title{
Gestational Diabetes Mellitus Knowledge of Pregnant Women and The Factors Affecting Knowledge: A Cross Sectional Study
}

\author{
Nuran Nur AYPAR AKBAĞ́
}

'Araş. Gör., Karamanoğlu Mehmetbey Üniversitesi, Sağlık Bilimleri Fakültesi, Hemşirelik Bölümü, Doğum ve Kadın Hastalıkları Hemşireliği Anabilim Dalı, Karaman, Türkiye.

${ }^{2}$ Doç. Dr., Dokuz Eylül Üniversitesi, Hemşirelik Fakültesi, Doğum ve Kadın Hastalıkları Hemşireliği Anabilim Dalı, İzmir, Türkiye.

\begin{abstract}
Background: Gestational Diabetes has been increasing recently. This condition, which can cause extremely negative results for the mother and baby, can be taken under control by removing the lack of information. Objectives: This study aimed to examine the knowledge levels of pregnant women concerning Gestational Diabetes Mellitus (GDM), and to determine the factors that affect the knowledge levels. Methods: This research was conducted as a descriptive cross-sectional study. The sample was comprised of 184 pregnant women. The research data were evaluated by the multiple regression analysis. Results: The mean score of GDM knowledge level of pregnant women is $40.10 \pm 19.56(\mathrm{~min}=$ $0, \max =88)$ points. Monthly mean income $(\beta=.185, \mathrm{t}=2.779, \mathrm{p}=.006)$, treatment method $(\beta=.318, \mathrm{t}=3.422, \mathrm{p}=.001)$, status of receiving education $(\beta=.267, t=4530, p=.000)$, pregnant women evaluated GDM knowledge which level $(\beta=-.348, t=6.008, p=.000)$, and person who gave the education $(\beta=.180, t=3.375, \mathrm{p}=.001)$ were determined to be predictors of Gestational Diabetes Mellitus knowledge $(\mathrm{R} 2=.66$, $\mathrm{F}=25.690, \mathrm{p}=.000)$. Conclusion: Having high income, receiving insulin treatment beside the diet, receiving education about GDM, thinking they have information about GDM, and multidisciplinary approach were found the factors affecting GDM knowledge.

Key Words: Gestational Diabetes Mellitus (GDM), Knowledge levels, Pregnancy, Nursing.
\end{abstract}

$\ddot{O} \mathbf{z}$

Gebelerin Gestasyonel Diabetes Mellitus Bilgisi ve Bilgiyi Etkileyen Faktörler: Kesitsel Çalışma

Giriş: Gestasyonel Diyabetes son zamanlarda artmaktadır. Anne ve bebek için son derece olumsuz sonuçlara neden olabilen bu durum bilgi eksikliği giderilerek kontrol altına alınabilir. Amaç: Bu çalışmada, Gestasyonel Diyabetes Mellitus (GDM)'lu gebelerin bilgi düzeylerinin incelenmesi ve bilgi düzeylerini etkileyen faktörlerin belirlenmesi amaçlanmıştır. Yöntem: Bu araştırma, tanımlayıcı kesitsel bir çalışma olarak yapılmıştır. Örneklem 184 gebe kadından oluşmuştur. Araştırma verileri çoklu regresyon analizi ile değerlendirilmiştir. Bulgular: Gebe kadınların GDM bilgi düzeyi puan ortalaması $40.10 \pm 19.56(\min =0$, maks $=88)$ puandır. Aylık ortalama gelir $(\beta=.185, t=2.779, p=.006)$, tedavi yöntemi $(\beta=.318, t=3.422, p=.001)$, eğitim alma durumu $(\beta=.267, t=4530, p=.000)$, gebelerin GDM bilgisini hangi düzeyde değerlendirdiği $(\beta=-.348, t=6.008, p=.000)$ ve eğitimi veren kişinin $(\beta=.180, t=3.375, p=.001)$ Gestasyonel Diyabetes Mellitus bilgisinin tahmin edicileri olduğu saptanmıştır $(\mathrm{R} 2=.66, \mathrm{~F}=25.690, \mathrm{p}=.000)$. Sonuç: Yüksek gelir sahibi olma, diyet yanında insülin tedavisi alma, GDM konusunda eğitim alma, GDM hakkında bilgi sahibi olduğunu düşünme ve multidisipliner yaklaşım GDM bilgisini etkileyen faktörler olarak bulunmuştur.

Anahtar Sözcükler: Gestasyonel Diabetes Mellitus (GDM), Bilgi düzeyleri, Gebelik, Hemşirelik.

Geliş Tarihi / Received: 06.11.2020 Kabul Tarihi / Accepted: 16.09.2021

Correspondence Author: Araş. Gör., Karamanoğlu Mehmetbey Üniversitesi, Sağlık Bilimleri Fakültesi, Hemşirelik Bölümü, Doğum ve Kadın Hastalıkları Hemşireliği Anabilim Dalı, Karaman, Türkiye. Telefon: +90(545)9141440 E-posta: nuraypar@gmail.com

Cite This Article: Aypar Akbağ NN, Aluş Tokat M. Gestational Diabetes Mellitus knowledge of pregnant women and the factors affecting knowledge: A cross sectional study. Dokuz Eylül Üniversitesi Hemşirelik Fakültesi Elektronik Dergisi. 2021; 14(4): 396- 403 
Antenatal managements of GDM is highly important in preventing diagnosis related maternal, fatal, and neonatal complications. However, pregnant women in some developing countries cannot always receive adequate antenatal care in accordance with standards. This situation may arise from deficiencies in the follow-up process, lack of requests for antenatal care, having difficulties in accessing care, and inadequate information about the disease (3-7).

Although the studies evaluating the knowledge levels of pregnant women with GDM are limited in the literature, there are studies mostly evaluating the GDM information of healthy pregnant women. In different studies conducted in Maharashtra (42\%) and Pondicherry $(67 \%)$ in India, it was stated that healthy pregnant women who received antenatal care had an average level of GDM knowledge $(8,9)$. In the study conducted by Alharthi et al. (2018), GDM knowledge of non-GDM Sudi women was evaluated, it was determined that very few of the women knew about the diagnosis of GDM $(15.9 \%)$. When the factors affecting GDM knowledge were evaluated, it was found that women who bachelor degree, multigravida and history of GDM had a higher rate of knowledge (67.7\%) about GDM than others. It was also stated that those living in center areas have higher knowledge than those living in rural areas (10). In another study conducted Thomas et al. (2019), it was found that the GDM information of pregnant women without GDM was higher in the third trimester compared to other trimesters. Also, it was determined pregnant women with a family history of Diabetes Mellitus had higher knowledge than those who had no history (11).

Similar factors were found to be effective in studies conducted with pregnant women with GDM. In United Arab Emirates, knowledge of diet and parity among women with GDM was stated factors affecting of carbohydrate knowledge score in results from the analysis of the multiple regression (12). Moreover, in a study that was participated women with GDM, it was reported that factors such as age 25-29, having a higher education level, working, family history of DM affect GDM knowledge level (7). As can be seen in studies, the effect of similar socio-demographic and obstetric characteristics on the level of knowledge was evaluated. However, it is predicted that knowledge level of pregnant women who diagnosed GDM will be affected by antenatal education and education contents in the process of disease management.

Health professionals have an important role in effective management of GDM. The knowledge levels of the women, and the factors that are affecting their knowledge levels should be identified by professionals in order to promote effective management of the disease. Moreover, determining the factors that will positively or negatively affect knowledge levels may be beneficial in order to ensure self-management of GDM.

Therefore, the purpose of this study is to determine knowledge levels of pregnant women with GDM, and all factors affecting the knowledge levels.

\section{Research Questions}

- What are the mean scores of GDM knowledge of pregnant women with GDM?

- What are the effect of socio-demographic characteristics, obstetric characteristics, and GDM education content variables on their GDM knowledge levels?

\section{Study Design}

\section{Methods}

This is a descriptive cross-sectional study.

\section{Place and Time of Study}

This study was conducted in obstetrics and perinatology polyclinics and clinics of three hospitals in Western Turkey. The research data were collected between October 2015 and April 2016.

\section{Study Population and Sampling}

The power analysis was used to calculate the sample size. The results of a study performed by Hussain et al (Gestational Diabetes Mellitus Knowledge Questionnaire mean of 10.01, $\mathrm{SD}=3.63$ ) was used for this analysis (7). Using the $\mathrm{G}$ power 3.1.9.4 program, the sample size was estimated to be 176 subjects (95\% power, $95 \%$ confidence interval). The post hoc statistical power analysis was performed at the end of the study and indicated $99 \%$ sufficient statistical power with 184 women.

Gestational diabetes was diagnosed in $24^{\text {th }}-28^{\text {th }}$ gestational weeks (according to the criteria of the American Diabetes Association [ADA]) (13) in obstetrics and gynecology polyclinics. Subsequently, the pregnant women with GDM, who were newly diagnosed with diabetes or who had started insulin treatment, were followed in the Diabetes Training Polyclinics. In these clinics, the participant women initially received individual education about diabetes mellitus management by certified diabetes nurses, or preferably they participated in group education program. Women who received education were registered into the hospital records. In addition, it was questioned whether or not the women participated in the diabetes education. The participant women were also informed by dietitians and physicians. No payment was made to the hospital for individual or group educations. Brochures were generally distributed during the patient educations. The inclusion criteria were determined as follows: having been diagnosed with GDM, having a pregnancy at the $24^{\text {th }}$ or over weeks, having a single fetus, and not being diagnosed with any psychological disorder.

\section{Data Collection Tools}

Three different data collection tools were used. Since data collection is not present in a valid and reliable scale that evaluates the level of knowledge of women with GDM, information forms prepared by taking expert opinion were used. Introductory and Obstetric Characteristics Form

This form included 10 questions about age, educational status, occupational status, economic level, spouse's educational status, family type, and medical information. 
Previous GDM Education Form

This form included 8 questions aiming to determine the number of previous education sessions, previous education methods, and the GDM trainers who provided the education.

\section{GDM Knowledge Form}

It included 30 questions about the development of GDM and risk factors, blood glucose monitoring, diet, exercise, and maternal, fetal, and neonatal results and complications. The form was prepared according to the literature and was evaluated by three domain-expert researchers (13-17). Finally, in order to determine the comprehensibility of the forms in terms of questions, a pilot study (30 participants) was conducted in a manner consistent with the questions forms. All questions were easily understood by the pregnant.

\section{Data Analysis}

The pregnant women were asked to respond the multi-choice questions and each correct answer was calculated as one point. Questions about insulin treatment were asked only to women who received insulin treatment. To prevent discrepancies between the GDM knowledge of pregnant women who used insulin and those who did not use insulin, total scores were calculated out of 100 . The statistical analysis was carried out in two stages. Firstly, the independent variables and the GDM knowledge level as depended variable were assessed with the Pearson Correlation. Variables associated with the GDM knowledge level were entered into the multiple regression model. By using independent variables, four regression models were created. The significance level was determined as 0.05 , and the confidence interval $(C I)$ was calculated as $95 \%$. The report of this study followed the Strengthening the Reporting of Observational Studies in Epidemiology (STROBE) (18).

\section{Ethical Considerations}

This study was administered with the principles of the Helsinki Declaration. Ethical committee approval was obtained from the Non-Intervention Research Assessment Commission in Dokuz Eylul University (Date:15/10/2015, No: 2317 GOA/23-15). Also, the participants were informed about the aim of the study, verbal and written permission was obtained.

Socio-demographic, obstetrical characteristics

\section{Results}

The mean age of the participants was $31.71 \pm 6.02$ years. Mostly of pregnant women (49\%) and their spouses (54.9\%) have primary school level education. The pregnant women with GDM mostly used diet and exercise (68.5\%) for current GDM treatment. It was stated that $20 \%$ of pregnant women thinking they have enough information about GDM. However, it was determined that only $86 \%$ of them received education about GDM. In addition, pregnant women received an average of $1.60 \pm 0.77$ times education (Table 1 ). 
Table 1. Socio-demographic, Obstetrical Characteristics of Pregnant Women and Their Status of Having Received Education about GDM

\begin{tabular}{|c|c|c|c|c|c|c|}
\hline & $n$ & $\%$ & $\bar{x}$ & $\pm S D$ & Min & Max \\
\hline Age & 184 & & 31.71 & 6.02 & 18 & 44 \\
\hline $\begin{array}{l}\text { Educational } \\
\text { Status } \\
\text { Literate } \\
\text { Primary School } \\
\text { High School } \\
\text { University and } \\
\text { above }\end{array}$ & $\begin{array}{l}17 \\
90 \\
47 \\
30\end{array}$ & $\begin{array}{c}9.2 \\
49 \\
25.5 \\
16.3\end{array}$ & & & & \\
\hline $\begin{array}{l}\text { Occupational } \\
\text { status } \\
\text { Working woman } \\
\text { Housewife }\end{array}$ & $\begin{array}{c}52 \\
132\end{array}$ & $\begin{array}{l}28.3 \\
71.7\end{array}$ & & & & \\
\hline $\begin{array}{l}\text { Monthly mean } \\
\text { income (TL)* }\end{array}$ & 180 & & 2112.23 & 1.27 & 500 & 7000 \\
\hline
\end{tabular}

\begin{tabular}{lcc}
\hline $\begin{array}{l}\text { Educational } \\
\text { status of spouse }\end{array}$ & & \\
Literate & 5 & 2.7 \\
Primary School & 101 & 54.9 \\
Secondary School & 43 & 23.4 \\
$\begin{array}{l}\text { University and } \\
\text { above }\end{array}$ & 35 & 19.0 \\
\hline
\end{tabular}

Obstetrical Characteristics

\begin{tabular}{llllll}
\hline Gestational week & 184 & 34.29 & 3.34 & 28 & 41 \\
\hline $\begin{array}{l}\text { The week when of } \\
\text { diagnosis }\end{array}$ & 184 & 25.83 & 2.61 & 24 & 37 \\
\hline
\end{tabular}

\section{Having previous}

$\begin{array}{lcc}\text { GDM } & 27 & 19.7 \\ \text { Yes } & 110 & 80.3\end{array}$

No

\begin{tabular}{lcc}
\hline $\begin{array}{l}\text { Treatment } \\
\text { method in } \\
\text { previous GDM }\end{array}$ & & \\
Diet & 19 & 70.4 \\
$\begin{array}{l}\text { Diet, exercise and } \\
\text { insulin }\end{array}$ & 5 & 18.5 \\
\end{tabular}

Untreated

\begin{tabular}{|c|c|c|}
\hline $\begin{array}{l}\text { Treatment } \\
\text { method }\end{array}$ & & \\
\hline Diet and exercise & 126 & 68.5 \\
\hline $\begin{array}{l}\text { Diet and insulin } \\
\text { treatment }\end{array}$ & 58 & 31.5 \\
\hline
\end{tabular}

\begin{tabular}{l}
\hline Status of Receiving Education about GDM \\
$\begin{array}{l}\text { How much do you } \\
\text { know about }\end{array}$ \\
GDM? \\
I have very much \\
knowledge
\end{tabular}




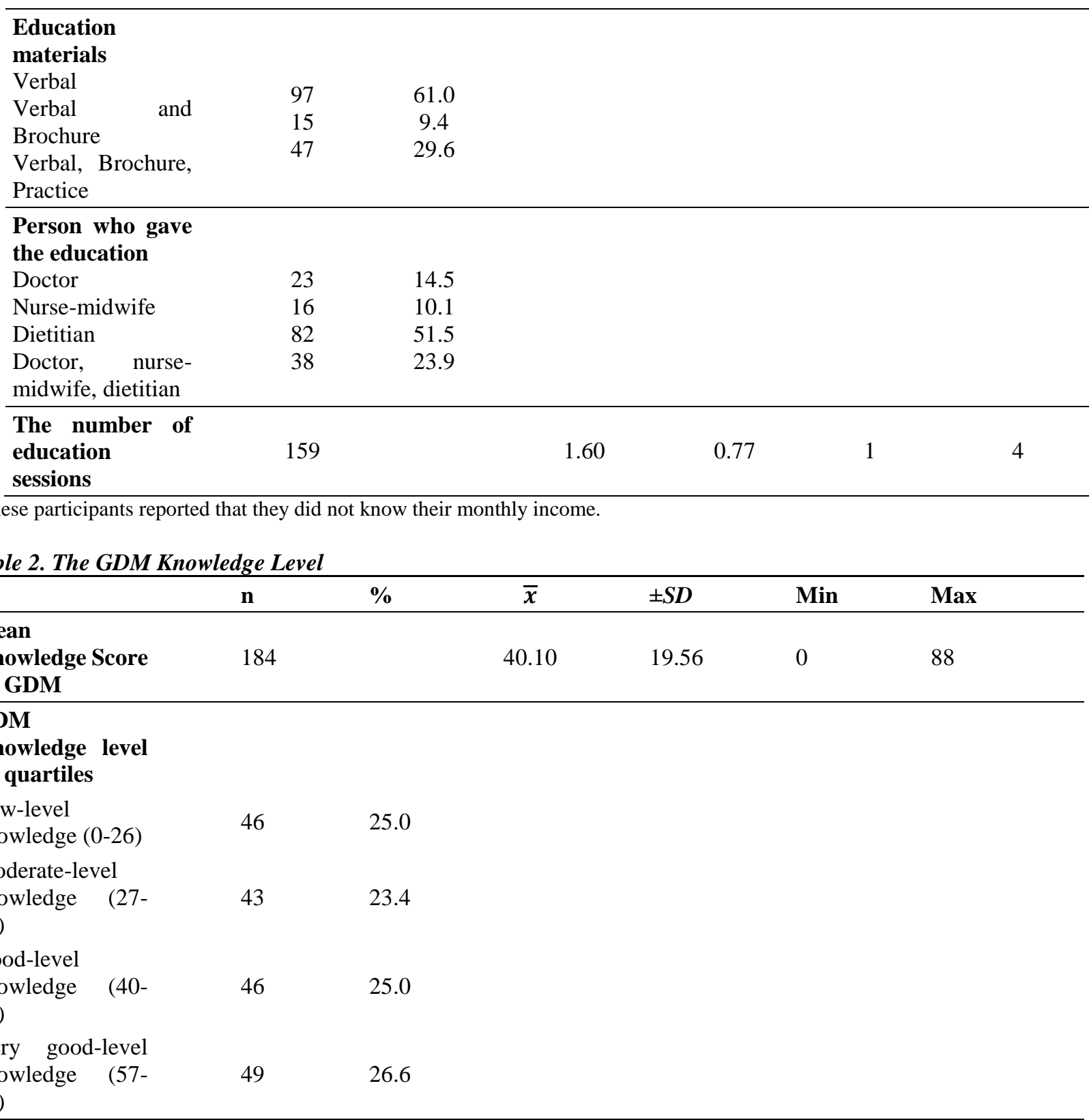

\section{Multiple regressions with all variables}

Four different model was created according to the relationship between the variables in the multiple regression analysis. As a result of the analysis, it was determined that socio-demographic characteristics in the Model 1 accounted for 30\% of the factors affecting the GDM knowledge level $(\mathrm{F}=15.87, \mathrm{p}=.000)$. Among these variables, age $(\beta=.207, \mathrm{t}=3.263$, $\mathrm{p}=.001)$, education level $(\beta=.314, \mathrm{t}=3.355, \mathrm{p}=.001)$ and monthly income level $(\beta=.232, \mathrm{t}=2.544, \mathrm{p}=.012)$ were found to be statistically significant predictors (Model 1).

The obstetric characteristics accounted for $14 \%$ of variance $(F=10.18, p=.000)$ (Model 2). The week of diagnosis and the treatment method were determined as affecting factors in this model.

Receiving to GDM education ( $\beta=.365, \mathrm{t}=2.526, \mathrm{p}=.012)$, thinking pregnant women have information about GDM $(\beta=-.503, t=9.961, p=.000)$, and multidisciplinary approach $(\beta=.251, t=4.500, p=.000)$ were the strongest predictors in Model 3 (58\%) for the GDM knowledge level $(\mathrm{F}=41.17, \mathrm{p}=.000)$.

Finally, it was found that monthly mean income $(\beta=.185, \mathrm{t}=2.779, \mathrm{p}=.006)$, treatment method $(\beta=.318, \mathrm{t}=3.422$, $\mathrm{p}=.001)$, status of receiving education $(\beta=.267, \mathrm{t}=4530, \mathrm{p}=.000)$, the knowledge that pregnant women evaluated GDM knowledge which level $(\beta=-.348, t=6.008, p=.000)$ and person who gave the education $(\beta=.180, t=3.375, p$ $=.001)$ have a significant effect on GDM knowledge. In Model 4, stepwise multiple regression analyses were performed and the analyses demonstrated that the model accounted for $66 \%$ of the whole variance $(\mathrm{F}=25.69, \mathrm{p}=.000)$. (Table 3$)$. 
Table 3. Predictors of Gestational Diabetes Mellitus Knowledge: Results of Multiple Regression $(n=184)$

\begin{tabular}{|c|c|c|c|c|}
\hline & Model 1 ${ }^{a}$ & Model $2^{b}$ & Model 3c & Model 4d \\
\hline Age & $\begin{array}{l}\beta=.207 \\
t=3.263 \\
p=.001 *\end{array}$ & & & $\begin{array}{c}\beta=.056 \\
\mathrm{t}=1.169 \\
\mathrm{p}=.244 * * *\end{array}$ \\
\hline Educational status & $\begin{array}{l}\beta=.314 \\
t=3.355 \\
p=.001 *\end{array}$ & & & $\begin{array}{c}\beta=.123 \\
\mathrm{t}=1.702 \\
\mathrm{p}=.091 * * *\end{array}$ \\
\hline Educational status of her spouse & $\begin{array}{c}\beta=.042 \\
\mathrm{t}=.474 \\
\mathrm{p}=.636^{* * *}\end{array}$ & & & $\begin{array}{c}\beta=.008 \\
\mathrm{t}=.125 \\
\mathrm{p}=.901 * * *\end{array}$ \\
\hline Occupational status & $\begin{array}{c}\beta=-.048 \\
t=-.599 \\
p=.550 * * *\end{array}$ & & & $\begin{array}{c}\beta=-.010 \\
\mathrm{t}=-.175 \\
\mathrm{p}=.862 * * *\end{array}$ \\
\hline Monthly mean income & $\begin{array}{c}\beta=.232 \\
\mathrm{t}=2.544 \\
\mathrm{p}=.012 * *\end{array}$ & & & $\begin{array}{c}\beta=.185 \\
t=2.779 \\
p=.006^{* *}\end{array}$ \\
\hline The week of diagnosis & & $\begin{array}{c}\beta=-.150 \\
\mathrm{t}=-2.143 \\
\mathrm{p}=.033 * *\end{array}$ & & $\begin{array}{c}\beta=-.060 \\
\mathrm{t}=-1.250 \\
\mathrm{p}=.213 * * *\end{array}$ \\
\hline Having a history of GDM & & $\begin{array}{c}\beta=.119 \\
\mathrm{t}=1.693 \\
\mathrm{p}=.092 * * *\end{array}$ & & $\begin{array}{c}\beta=.067 \\
\mathrm{t}=1.424 \\
\mathrm{p}=.156 * * *\end{array}$ \\
\hline Treatment method (Diet-Insulin Treatment) & & $\begin{array}{l}\beta=.292 \\
t=4.184 \\
p=.000^{*}\end{array}$ & & $\begin{array}{l}\beta=.318 \\
t=3.422 \\
p=.001 *\end{array}$ \\
\hline How much do you know about GDM? & & & $\begin{array}{l}\beta=-.503 \\
t=9.961 \\
p=.000^{*}\end{array}$ & $\begin{array}{l}\beta=-.348 \\
t=6.008 \\
p=.000 *\end{array}$ \\
\hline Receiving education & & & $\begin{array}{c}\beta=.365 \\
\mathrm{t}=2.526 \\
\mathrm{p}=.012 * *\end{array}$ & $\begin{array}{l}\beta=.267 \\
t=4.530 \\
p=.000^{*}\end{array}$ \\
\hline The number of education sessions & & & $\begin{array}{c}\beta=-.028 \\
\mathrm{t}=-.443 \\
\mathrm{p}=.658 * * *\end{array}$ & $\begin{array}{c}\beta=-.034 \\
\mathrm{t}=.564 \\
\mathrm{p}=.573 * * *\end{array}$ \\
\hline $\begin{array}{l}\text { Receiving education from doctor, nurse and } \\
\text { dietitian }\end{array}$ & & & $\begin{array}{l}\beta=.251 \\
t=4.500 \\
p=.000^{*}\end{array}$ & $\begin{array}{l}\beta=.180 \\
t=3.375 \\
p=.001 *\end{array}$ \\
\hline $\begin{array}{l}\text { Education materials (verbal, brochure and } \\
\text { practice) }\end{array}$ & & & $\begin{array}{c}\beta=-.082 \\
\mathrm{t}=1.486 \\
\mathrm{p}=.139 * * *\end{array}$ & $\begin{array}{c}\beta=-.156 \\
\mathrm{t}=-1.649 \\
\mathrm{p}=.101 * * *\end{array}$ \\
\hline $\mathbf{R}$ & .55 & .38 & .76 & .81 \\
\hline $\mathbf{R}^{2}$ & .30 & .14 & .58 & .66 \\
\hline $\mathbf{F}$ & 15.870 & 10.180 & 41.176 & 25.690 \\
\hline $\mathbf{p}$ & .000 & .000 & .000 & .000 \\
\hline
\end{tabular}

${ }^{\text {a Model } 1}$ The effect of socio-demographic characteristics on GDM knowledge score

${ }^{b}$ Model 2 The effect of obstetrical characteristics on GDM knowledge score

${ }^{\text {c Model }} 3$ The effect of receiving education about GDM on GDM knowledge score

${ }^{\mathbf{d}}$ Model 4 The effect of all predictors on GDM knowledge score $* \mathrm{p}<.001, * * \mathrm{p}<.05, * * * \mathrm{p}>.05$

\section{Discussion}

The average GDM knowledge score of Turkish pregnant women in this study were determined to be below the average. It was found in the present study that many factors had an effect on the GDM knowledge levels of pregnant women. This may be due to the inadequate number of qualified staff, insufficient time, and the absence of a structured education to provide effective training in our country.

In the first regression model, the effect of socio-demographic characteristics on GDM knowledge was analyzed. According to the results of the first model, it was determined that increasing age, education status and monthly mean income affect positively GDM knowledge. The findings of Hussain et al., (2015) revealed that glycemic control was 
better managed by the pregnant women with GDM in the 25-29 age group and their knowledge levels were higher compared to pregnant women in the older age groups (7). When the effectiveness of the educational situation was evaluated, it was reported in a qualitative study (2017) that Spanish women living in Mexico with a high level of education managed GDM more easy than women with a lower education level (19). Additionally, Hussain et al., (2015) revealed that working women with GDM had higher levels of knowledge about GDM and they could control better their glycemic index, compared to housewives (7). The motive behind the increasing knowledge scores with increasing age can be explained by increasing awareness with advancing age, or becoming more open and alert to learning based on increased health risks of a pregnant woman with an advanced age. The increasing education status can be explained by the fact that learning skills and knowledge about access to health care can be improved with higher education. Also, it is thought that business life can give more opportunity for education and more exposure to health information. Our results demonstrated that the educational status of the spouses was not correlated with the GDM knowledge level. However, contrary to our results, it was reported in a study that higher educational levels of spouses had a positive effect (4). In another study, it was determined that social support improved the lifestyle behaviors (20) and increased the rate of admittance to hospitals for antenatal care (4) among women with histories of GDM. This conflicting result may have emerged from whether sharing the pregnancy responsibilities with the spouse. In Turkey, pregnancy is generally seen as a responsibility of women and they generally shoulder this process on themselves.

In the second model, it was demonstrated in the findings that the early week of diagnosis and that receiving insulin treatment beside the diet was an important predictor of GDM knowledge score. In a study was demonstrated that women with late diagnosis can negatively affect GDM knowledge and reduce the opportunity to manage the disease (19). When the effect of the treatment method was evaluated, it was reported that pregnant women, who were managing the disease process solely through diet, had lower levels of knowledge about GDM management compared to those receiving diet and insulin treatment together (7). If a pregnant woman considers insulin treatment as a serious step, this may have an effect on increasing the knowledge level. Because, in Turkey, insulin education is more formal and standard; therefore, knowledge level of a pregnant woman may be higher compared to those struggling with the disease solely with the diet. In addition, in our study result, it was found that having a previous GDM history was not correlated with GDM knowledge score. On the contrary this result, Jones et al., (2012) reported that women with a history of GDM had high levels of perception and knowledge about Type 2 DM and the associated cardio metabolic risks (21). Because pregnant women with a history of GDM have higher levels of awareness about possible risks; therefore, they have less difficulty in changing their life style. However, the women, who were not informed by health professionals in the past and who had no access to information, are not expected to benefit from this experience. It is thought that more innovative education opportunities can be offered to women who have a history of GDM by using these experiences.

In the third model of this study, GDM awareness levels of the pregnant women were negatively correlated with their GDM knowledge status; this may be considered as a negative result. When pregnant women are not aware of the fact that health information is required, it may be more difficult for health care professionals to get women to participate in education programs. In our model, the status of receiving a previous education was positively related with the GDM knowledge score. A study conducted by Şen and Şirin (2014) in Turkey, it was determined that education program increased the GDM knowledge scores of the pregnant women (22). However, in Turkey, women are not generally aware of the adequacy of their knowledge about diseases, and they do not use information sources sufficiently. The major sources of information of women are television/radio, neighbors/friends, nurses, midwives, and family members in South India as well as in our country (23). In addition, the education provided through the cooperation of the doctor, nurse-midwife, and dietitian affected pregnant women more positively. The multidisciplinary approach improves patient confidence and facilitates behavior changes. Our results demonstrated that the number of education sessions and education materials (verbal, brochure, and practice) were not correlated with the GDM knowledge level. However, researchers revealed that education will be effective when it is provided with adequate frequency, and using various teaching methods. A study conducted by Al-Maskari et al., (2013) determined that using a combination of teaching methods such as narration, handing out brochures, and implementing practices is believed to make it easier for people to comprehend and retain knowledge, and to integrate the information into their lives (24). In our country, education materials and number of education sessions do not have an influence alone, which is considered to be affected from the lack of other factors.

All of the variables that are examined in this study account for $66 \%$ of the influential factors for the GDM knowledge score (Model 4). Unlike the other three models, the same results were predictor in all other variables except for the age, education and week of diagnosis. Similarly, in other studies were stated that pregnant women with GDM, who had a high monthly mean income, received insulin treatment beside the diet, and received education about GDM from a multidisciplinary group, have increased GDM knowledge level $(7,22,24)$. Our result, that were different and the most striking predictor, from other studies, was that pregnant women who think that they have high GDM knowledge actually have low GDM knowledge. It may be very difficult to include pregnant women who have this feature in the antenatal education process. An objective evaluation of the knowledge level of women who have low awareness and who thinking own knowledge is sufficient can increase awareness.

\section{Limitations}

People from different social, economic, and cultural levels live in different parts of Turkey. Although the province, where this study was conducted, and the hospitals, where these practices were performed, serve patient groups from many different regions of the country, the fact that this study was conducted only in a single province may be a limitation. Additionally, the educations were not standard due to the fact that the hospital resources vary across the country (basically due to the insufficiency of the diabetes polyclinics and lack of trained personnel), the education 
sessions were not regular for each woman with GDM since the sessions were implemented in accordance with the availability of the participants, and there was no regular follow-up system. Irregular education sessions and irregular follow-up system can be accepted as another limitation of the study.

\section{Use of Results in Practice}

The pregnant women in Turkey and around the globe may have pregnancy risks since they are poorly informed about their GDM. Some sociodemographic and obstetrical factors and having a previous GDM education contribute to the GDM knowledge levels of the pregnant women in Turkey. According to these factors, a more effective education can be performed in terms of content and duration. Positive changes can be provided for women by improving the policies applied in the country, facilitating access to health services, increasing health service delivery, and through structured training. Since the variables account for $66 \%$ of the factors affecting the GDM knowledge levels in this study, future studies should identify other factors that may affect the knowledge levels. It is recommended for future studies to examine the relationships between GDM knowledge level and pregnancy outcomes.

\section{Acknowledgement}

This study was approved by the Non-Intervention Research Assessment Commission in a university (Date:15/10/2015, No: 2317 GOA/23-15). The authors declare that they have no competing interests. No funding was received for this study. Each author's has 100\% contribution. Study conception and design, data analysis and interpretation and drafting of the article were made by all authors. In this study, data were collected by the first author. 


\section{References}

1. International Diabetes Federation (IDF). Diabetes Atlas. Ninth Edition. (2019). ISBN: 978-2-930229-87-4. https://www.diabetesatlas.org/en/ 03 October 2021.

2. Karacam Z, Celik D. The prevalence and risk factors of gestational diabetes mellitus in Turkey: a systematic review and meta-analysis. J Matern Fetal Neonatal Med, 2021;34(8):1331-1341.

3. Joshi C, Torvaldsen S, Hodgson R, Hayen A. Factors associated with the use and quality of antenatal care in Nepal: a population-based study using the demographic and health survey data. BMC Pregnancy Childbirth 2014;14(94):1-11.

4. Shrestha S, Thapa P, Saleh S, Thapa N, Stray BP, Khanom K. Knowledge of diabetes mellitus among pregnant women in three districts of Nepal. J Nepal Health Res Counc 2013;11:259-263.

5. Titaley CR, Dibley MJ, Roberts CL. Factors associated with underutilization of antenatal care services in Indonesia: results of Indonesia demographic and health survey 2002/2003 and 2007. BMC Public Health 2010;10(485):1-10.

6. Yeoh PL, HornetzK, Dahlui M. Antenatal care utilization and content between low-risk and high-risk pregnant women. PLoS ONE 2016;11(3):e0152167.

7. Hussain Z, Yusoff ZM, Sulaiman AS. Evaluation of knowledge regarding gestational diabetes mellitus and its association with glycemic level: a Malaysian study. Prim Care Diabetes 2015;9(3):184-190.

8. Bhalge UU, Bhise MD, Takalkar AA, Gaikwad BS. Knowledge of gestational diabetes mellitus among antenatal women in rural area of Maharashtra. Int J Community Med 2019;6(10):4443-4446.

9. Elamurugan S, Arounassalame B. What do mothers know about gestational diabetes: knowledge and awareness. Indian J Obstet Gynecol Res 2016;3(4),393-396.

10. Alharthi AS, Althobaiti KA, Alswat KA. (2018). Gestational diabetes mellitus knowledge assessment among Saudi women. Open Access Maced J Med Sci 2018;6(8):1522-1526.

11. Thomas S, Pienyu R, Rajan SK. Awareness and Knowledge about gestational diabetes mellitus among antenatal women. Psychology, Community \& Health 2020;8(1):237-248.

12. Ali HI, Jarrar AH, El Sadig M, Yeatts KB. (2013). Diet and carbohydrate food knowledge of multi-ethnic women: a comparative analysis of pregnant women with and without gestational diabetes mellitus. PLoS One 2013;8(9):e73486.

13. American Diabetes Association (ADA). Standards of medical care in diabetes. Diabetes Care 2016;39(1):94-98.

14. Hod M, Kapur A, Sacks AD, Hadar E, Agarwal M, Di Renzo GC, et al. The International Federation of Gynecology and Obstetrics (FIGO) Initiative on gestational diabetes mellitus: a pragmatic guide for diagnosis, management, and care. Int J Gynaecol Obstet 2015;131:173-211.

15. National Institute for Health and Care Excellence (NICE). Diabetes in pregnancy: management of diabetes and its complications from preconception to the postnatal period, NICE Guideline 2015;3:1-651.

16. The American College of Obstetricians and Gynecologists (ACOG). Physical activity and exercise during pregnancy and the postpartum period, Committee Opinion. (2015) Number 650. https://www.acog.org//media/project/acog/acogorg/clinical/files/committee-opinion/articles/2015/12/physical-activity-and-exerciseduring-pregnancy-and-the-postpartum-period.pdf 03 October 2021.

17. Türkiye Endokrinoloji ve Metabolizma Derneği (Endocrinology and Metabolism Association of Turkey [TEMD]). (2020). Diabetes mellitus ve komplikasyonlarının tanı, tedavi ve izlem kılavuzu (Diagnosis and treatment of temd diabetes mellitus and complications) (14th ed.). Ankara: Bayt Printing Press. ISBN: 978-605-4011-40-7.

18. von Elm E, Altman DG, Egger M, Pocock SJ, Gøtzsche PC, Vandenbroucke JP. The strengthening the reporting of observational studies in epidemiology (STROBE) statement: guidelines for reporting observational studies. Bulletin of the World Health Organization 2007;85(11):867-872.

19. Carolan-Olah M, Duarte-Gardea M, Lechuga J, Salinas-Lopez S. The experience of gestational diabetes mellitus (GDM) among Hispanic women in a U.S. border region. Sex Reprod Healthc 2017;12:16-23.

20. Gonenc IM, Duyan V, Ilhan Erkal S, Purutcuoglu E, Kaan Guven H. Investigation of the effect of education in pregnancy on the focus of fetal health control. The Journal of Gynecology-Obstetrics and Neonatology 2016;13:12-17.

21. Jones EJ, Appel SJ, Eaves YD, Moneyham L, Oster RA, Ovalle F. Cardio metabolic risk, knowledge, risk perception, and self-efficacy among American Indian women with previous gestational diabetes. J Obstet Gynecol Neonatal Nurs 2012;41:246-257.

22. Sen E, Sirin A. The effect of gestational diabetes mellitus training upon metabolic control, maternal and neonatal outcomes. International Journal of Caring Sciences 2014;7:313-323.

23. Shriraam V, Rani MA, Sathiyasekaran BWC, Mahadevan S. Awareness of gestational diabetes mellitus among antenatal women in a primary health center in South India. Indian J Endocrinol Metab 2013;17(1):146-148.

24. Al-Maskari F, El-Sadig M, Al-Kaabi JM, Afandi B, Nagelkerke N, Yeatts KB. Knowledge, attitude and practices of diabetic patients in the United Arab Emirates. Plos One 2013;8(1): e52857. 